\title{
Rheological and Pipe Flow Properties of Chocolate Masses at Different Temperatures
}

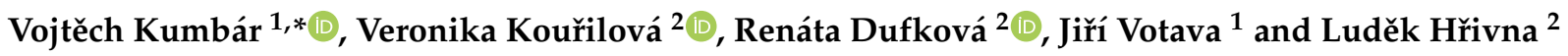 \\ 1 Department of Technology and Automobile Transport (Section Physics), Faculty of AgriSciences, Mendel \\ University in Brno, Zemědělská 1, 61300 Brno, Czech Republic; jiri.votava@mendelu.cz \\ 2 Department of Food Technology, Faculty of AgriSciences, Mendel University in Brno, Zemědělská 1, \\ 61300 Brno, Czech Republic; veronika.kourilova@mendelu.cz (V.K.); renata.dufkova@mendelu.cz (R.D.); \\ hrivna@mendelu.cz (L.H.) \\ * Correspondence: vojtech.kumbar@mendelu.cz; Tel.: +420-545132128
}

\section{check for}

updates

Citation: Kumbár, V.; Kouřilová, V.; Dufková, R.; Votava, J.; Hřivna, L. Rheological and Pipe Flow Properties of Chocolate Masses at Different Temperatures. Foods 2021, 10, 2519. https://doi.org/10.3390/ foods10112519

Received: 7 September 2021

Accepted: 19 October 2021

Published: 20 October 2021

Publisher's Note: MDPI stays neutral with regard to jurisdictional claims in published maps and institutional affiliations.

Copyright: (c) 2021 by the authors. Licensee MDPI, Basel, Switzerland. This article is an open access article distributed under the terms and conditions of the Creative Commons Attribution (CC BY) license (https:/ / creativecommons.org/licenses/by/ $4.0 /)$.
Abstract: Chocolate masses are one of the basic raw materials for the production of confectionery. Knowledge of their rheological and flow behaviour at different temperatures is absolutely necessary for the selection of a suitable technological process in their production and subsequent processing. In this article, the rheological properties (the effect of the shear strain rate on the shear stress or viscosity) of five different chocolate masses were determined-extra dark chocolate (EDC), dark chocolate (DC), milk chocolate (MC), white chocolate (WC), and ruby chocolate (RC). These chocolate masses showed thixotropic and plastic behaviour in the selected range of shear rates from 1 to $500 \mathrm{~s}^{-1}$ and at the specified temperatures of $36,38,40,42$, and $44{ }^{\circ} \mathrm{C}$. The degree of thixotropic behaviour was evaluated by the size of the hysteresis area, and flow curves were constructed using the Bingham, Herschel-Bulkley and Casson models with respect to the plastic behaviour of the chocolate masses. According to the values of the coefficients of determination $\mathrm{R}^{2}$ and the sum of the squared estimate of errors (SSE), the models were chosen appropriately. The most suitable models are the Herschel-Bulkley and Casson models, which also model the shear thinning property of the liquids (pseudoplastic with a yield stress value). Using the coefficients of the rheological models and modified equations for the flow velocity of technical and biological fluids in standard piping, the $2 \mathrm{D}$ and $3 \mathrm{D}$ velocity profiles of the chocolate masses were further successfully modelled. The obtained values of coefficients and models can be used in conventional technical practice in the design of technological equipment structures and in current trends in the food industry, such as 3D food printing.

Keywords: chocolate masses; temperature; rheology; thixotropy; pipe flow velocity; mathematical models; 2D and 3D flow profiles

\section{Introduction}

Chocolate is generally very popular worldwide and consumed across all generations. Its popularity is closely related to its overall sensory properties [1]. In order for chocolate to be called chocolate, it must meet legislative requirements for each type of chocolate. Dark chocolate contains at least $18 \%$ by weight of cocoa butter, $14 \%$ fat-free cocoa components, and the total content of cocoa components should be at least 35\%. Milk chocolate means a product containing at least $25 \%$ of total cocoa components, at least $14 \%$ of milk solids, at least $2.5 \%$ of fat-free cocoa components, at least $3.5 \%$ of milk fat, and at least $25 \%$ of total fat, which is the sum of the cocoa butter and milk fat [2]. White chocolate is made from cocoa butter, milk or dairy products, sweeteners, or other ingredients $[3,4]$. According to the current legislation, white chocolate must contain at least $20 \%$ cocoa butter, at least $14 \%$ milk solids, with at least 3.5\% milk fat [2]. Recipe choice of dairy ingredient affects the strength of the finished product [5]. In contrast to the above-mentioned types of chocolates, there is also ruby chocolate. The Belgian-Swiss company Barry Callebaut brought ruby chocolate 
to the world market in 2017. The exact technological process of production is not known, it is the know-how of the above-mentioned company, which patented ruby chocolate in 2012 [6,7]. However, the standard for chocolate and chocolate products has not yet officially recognised ruby chocolate as the fourth type of chocolate [8]. Although this type of chocolate is not yet covered by European legislation, it can be called chocolate because, according to the information on the packaging, it contains at least $47 \%$ cocoa components and at least $26 \%$ milk solids. The basic component of quality chocolate is cocoa butter, in which the other components are dispersed, which differ according to the type of chocolate. Cocoa butter forms a so-called continuous phase in chocolate, which forms a network structure for the spatial retention of the dispersed components. Cocoa butter can crystallise in a number of polymorphic forms as a function of triglyceride composition, with fatty acid composition influencing how liquid fat solidifies. Cocoa butter has six polymorphic forms (I-VI), the principals being $\alpha, \beta$, and $\beta^{\prime}$. Form $\mathrm{V}$, a $\beta$ polymorph, is the most desirable form (in general) in well-tempered chocolate, giving a glossy appearance, good snap, contraction, and resistance to bloom. If chocolate is poorly tempered, the outcome is the $\beta$ Form IV, which rapidly transforms into Form V. This influences colour as reflected light is disoriented by unstable, disorganised crystal growth. Untempered chocolate is soft and not effectively demoulded. In cocoa butter, Forms V and VI are the most stable forms. Form VI is difficult to generate although it is formed by lengthy storage of tempered chocolate accompanied by fat bloom. In addition, Form VI has a high melting temperature $\left(36^{\circ} \mathrm{C}\right)$ and crystals that are large and gritty on the tongue. The unstable Form I has a melting point of $17^{\circ} \mathrm{C}$ and is rapidly converted into Form II that transforms more slowly into III and IV. Tempering has four key steps: melting to completion (at $50^{\circ} \mathrm{C}$ ), cooling to point of crystallisation (at $32{ }^{\circ} \mathrm{C}$ ), crystallisation $\left(\right.$ at $27^{\circ} \mathrm{C}$ ), and conversion of any unstable crystals (at $29-31^{\circ} \mathrm{C}$ ). For chocolate to be in an appropriate polymorphic form, tempering is crucial, influencing final quality characteristics such as colour, hardness, handling, finish, and shelflife characteristics [3]. Thus, liquid chocolate is a complex polydisperse system and the relationships between the individual components determine the physical and rheological properties of the chocolate $[4,9,10]$. As the shear rate increases, the chocolate becomes more fluid, i.e., has a lower viscosity, due to the disintegration of the polydisperse chocolate system $[3,11,12]$. The rheological and textural properties of the chocolate are affected by its specific composition, especially the content of the fats, sugars, milk, other milk components, and surfactants. The fat content of chocolates is usually in the range of $25-35 \%$ [3]. The fat content has a significant effect on changes in the plastic viscosity. If chocolate contains a $28-32 \%$ fat content, these changes are more pronounced than for chocolates with a fat content above 32\% [12]. Melted chocolate exhibits non-Newtonian plastic fluid behaviour, with shear thinning when the yield stress is exceeded [3]. The magnitude of this shear stress depends on the temperature of the chocolate, in this case, an indirect ratio applies, so the more the chocolate is heated, the less shear stress is needed to initiate the flow, the so-called yield stress [13]. Rheological models according to Herschel-Bulkley and Casson are widely used to model flow curves, respectively, to model the behaviour of non-ideal plastic liquids, so they could be useful for chocolate materials.

Based on the introductory literature review, the following two scientific hypotheses were established. These hypotheses are not completely verifiable in the contemporary literature, so they are given due attention in this article.

- Chocolate masses have a plastic property with shear thinning behaviour (pseudoplastic with a yield stress).

- With an increasing temperature, the plastic viscosity or the consistency (depends on used rheological model) and thixotropy of the chocolate masses decreases.

\section{Materials and Methods}

\subsection{Samples of Chocolate Masses}

This research includes and describes the behaviour of chocolate masses that do not contain cocoa butter substitutes. Five chocolate masses were used for the experiments-extra 
dark chocolate (EDC), dark chocolate (DC), milk chocolate (MC), white chocolate (WC), and ruby chocolate $(\mathrm{RC})$.

The EDC (Domori, Italy) contains 100\% cocoa components (Morogoro, Tanzania). The DC, MC, and WC (Belcolade, Switzerland) contain 55.5\%, 36.5\%, and 28\% cocoa components. The RC (Callebaut, Belgium) contains $47.3 \%$ cocoa components. Further characteristics (nutritional data) of the chocolate masses are given in Table 1.

Table 1. Nutritional data of the chocolate masses.

\begin{tabular}{|c|c|c|c|c|c|c|}
\hline \multirow{3}{*}{$\begin{array}{l}\text { Chocolate } \\
\text { Mass }\end{array}$} & \multicolumn{5}{|c|}{ Nutritional Information Per $100 \mathrm{~g}$} & \multirow[b]{3}{*}{ Composition } \\
\hline & & Fats & Carbohydrates & & & \\
\hline & $\begin{array}{l}\text { Energy } \\
\text { Value }\end{array}$ & $\begin{array}{l}\text { Of Which } \\
\text { Saturated } \\
\text { Fatty Acids }\end{array}$ & $\begin{array}{l}\text { Of Which } \\
\text { Sugars }\end{array}$ & Proteins & Salt & \\
\hline EDC & $2576.0 \mathrm{~kJ}$ & $\begin{array}{l}53.0 \mathrm{~g} \\
20.0 \mathrm{~g}\end{array}$ & $\begin{array}{c}14.6 \mathrm{~g} \\
1.0 \mathrm{~g}\end{array}$ & $15.0 \mathrm{~g}$ & $0.2 \mathrm{~g}$ & $100 \%$ cocoa components \\
\hline DC & $2264.6 \mathrm{~kJ}$ & $\begin{array}{l}35.0 \mathrm{~g} \\
21.6 \mathrm{~g}\end{array}$ & $\begin{array}{l}46.9 \mathrm{~g} \\
44.0 \mathrm{~g}\end{array}$ & $5.7 \mathrm{~g}$ & $<0.005 \mathrm{~g}$ & $\begin{array}{l}55.5 \% \text { cocoa components, sugar, cocoa } \\
\text { butter }(35.0 \%) \text {, emulsifier: soy lecithin } \\
\text { (E322), aroma: natural vanilla }\end{array}$ \\
\hline $\mathrm{MC}$ & $2297.2 \mathrm{~kJ}$ & $\begin{array}{l}33.3 \mathrm{~g} \\
20.4 \mathrm{~g}\end{array}$ & $\begin{array}{l}55.6 \mathrm{~g} \\
54.7 \mathrm{~g}\end{array}$ & $5.8 \mathrm{~g}$ & $0.206 \mathrm{~g}$ & $\begin{array}{l}36.5 \% \text { cocoa components, sugar, cocoa } \\
\text { butter }(29.0 \%) \text {, whole milk powder, lactose, } \\
\text { whey powder, emulsifier: soy lecithin } \\
\text { (E322), aroma: natural vanilla }\end{array}$ \\
\hline WC & $2360.5 \mathrm{~kJ}$ & $\begin{array}{l}35.1 \mathrm{~g} \\
21.3 \mathrm{~g}\end{array}$ & $\begin{array}{l}56.1 \mathrm{~g} \\
56.1 \mathrm{~g}\end{array}$ & $6.4 \mathrm{~g}$ & $0.234 \mathrm{~g}$ & $\begin{array}{l}28 \% \text { cocoa components, sugar, cocoa butter } \\
(28 \%) \text {, whole milk powder, emulsifier: soy } \\
\text { lecithin (E322), aroma: natural vanilla }\end{array}$ \\
\hline $\mathrm{RC}$ & $2356.0 \mathrm{~kJ}$ & $\begin{array}{l}35.9 \mathrm{~g} \\
21.5 \mathrm{~g}\end{array}$ & $\begin{array}{l}49.6 \mathrm{~g} \\
48.5 \mathrm{~g}\end{array}$ & $9.3 \mathrm{~g}$ & $0.270 \mathrm{~g}$ & $\begin{array}{c}47.3 \% \text { cocoa components, sugar, cocoa } \\
\text { butter, whole milk powder, emulsifier: soy } \\
\text { lecithin (E322), acidity regulator: citric acid, } \\
\text { aroma: natural vanilla }\end{array}$ \\
\hline
\end{tabular}

EDC — extra dark chocolate, DC—-dark chocolate, MC - milk chocolate, WC—white chocolate, RB-ruby chocolate.

The individual chocolate masses were tempered (by the manufacturer) before distribution and used in this research in the form of chocolate drops. For completeness of sample characteristics, the specific tempering curves of chocolate masses are given in Table 2.

Table 2. Specific tempering temperatures of chocolate masses.

\begin{tabular}{cccc}
\hline & Melting Temperature, ${ }^{\circ} \mathbf{C}$ & Cooling Temperature, ${ }^{\circ} \mathbf{C}$ & Working Temperature, ${ }^{\circ} \mathbf{C}$ \\
\hline EDC & 55 & $28.5-29.5$ & $29.5-30.5$ \\
DC & $45-50$ & $28-29$ & $31-32$ \\
MC & $40-45$ & $27-28$ & $30-31$ \\
WC & $40-42$ & $25-26$ & $28-29$ \\
RC & 45 & 27 & $28.5-29.5$ \\
\hline
\end{tabular}

The chocolate masses were approximately the same age (difference of 2 weeks in the maximum between the productions of individual masses). Prior to analysis, the masses were stored under the same conditions in a single warehouse at $12{ }^{\circ} \mathrm{C}$.

\subsection{Rheological Measurements}

The rheological properties of the chocolate masses were measured using an RST CC rotary rheometer (AMATEK Brookfield, Middleboro, MA, USA) with a cone-plate measuring geometry. The diameter of the cone was $50 \mathrm{~mm}$ with an angle of $2^{\circ}$ (the 
standard designation is RCT-50-2). The gap between the cone and the plate was set to $0.05 \mathrm{~mm}$ at the narrowest point (at the tip of the cone), the gap was $0.923 \mathrm{~mm}$ at the edge of the cone. The measurement methodology was set appropriately, as the maximum size of the solid particles in the chocolate masses is $25 \mu \mathrm{m}[14,15]$. The measurements of the chocolate masses were performed at five different temperatures of $36,38,40,42$, and $44{ }^{\circ} \mathrm{C}$. Each measurement was repeated three times at an increasing shear strain rate (from 1 to $500 \mathrm{~s}^{-1}$ ) and three times at a decreasing shear strain rate (from 500 to $1 \mathrm{~s}^{-1}$ ) each time for $60 \mathrm{~s}$. The average values of the shear stress were then used for the mathematical modelling.

\subsection{Hysteresis Loop Test}

Thixotropic behaviour of five different chocolate masses was characterize by hysteresis loop test [16]: Shear rate was increased logarithmically from 1 to $500 \mathrm{~s}^{-1}$ in $1 \mathrm{~min}$, held constant at $500 \mathrm{~s}^{-1}$ in $10 \mathrm{~s}$, and decreased logarithmically from 500 to $1 \mathrm{~s}^{-1}$ in $1 \mathrm{~min}$. The flow measurements were performed by RST CC rotary rheometer (AMATEK Brookfield, Middleboro, MA, USA) with cone-plate geometry equipped with an RCT-50-2 spindle (diameter of the cone was $50 \mathrm{~mm}$ with an angle of $2^{\circ}$ ) at the temperatures of $36,38,40$, 42 , and $44{ }^{\circ} \mathrm{C}$. The hysteresis area was calculated with the use the corporate software, Rheo3000 (AMATEK Brookfield, Middleboro, MA, USA).

\subsection{Mathematical Modelling}

The dependence of the shear stress on the shear strain rate was described by three nonNewtonian (plastic) mathematical models. The first model was the Bingham rheological model [17]:

$$
\tau=\tau_{0}+\eta_{B} \dot{\gamma}
$$

The second model was the Herschel-Bulkley rheological model [18]:

$$
\tau=\tau_{0}+K \dot{\gamma}^{n}
$$

And the third model was the Casson rheological model [19]:

$$
\sqrt{\tau}=\sqrt{\tau_{0}}+\sqrt{\eta_{C} \dot{\gamma}}
$$

which can also be expressed as:

$$
\tau=\tau_{0}+2 \sqrt{\tau_{0} \eta_{C} \dot{\gamma}}+\eta_{C} \dot{\gamma}
$$

where $\tau$ is the shear stress $[\mathrm{Pa}], \tau_{0}$ is the yield stress $[\mathrm{Pa}], \eta_{B}$ is the Bingham plastic viscosity $[\mathrm{Pa} \cdot \mathrm{s}], \dot{\gamma}$ is the shear strain rate $\left[\mathrm{s}^{-1}\right], K$ is the consistency factor $\left[\mathrm{Pa} \cdot \mathrm{s}^{\mathrm{n}}\right], n$ is the flow index $[-]$, and $\eta_{C}$ is the Casson plastic viscosity $[\mathrm{Pa} \cdot \mathrm{s}]$.

\subsection{Statistical Analysis}

The experimental data were processed by MATLAB R2018b (MathWorks, Natick, MA, USA) and Statistica 12 (StatSoft, Tulsa, OK, USA). To determine a statistically significant difference between the measured values of the shear stress and dynamic viscosity at the selected temperatures of the individual chocolate masses, an ANOVA (analysis of variance) test was performed followed by multiple comparisons using Tukey's HSD (honestly significant difference) test (at the significance level of $p<0.05$ ).

The normality and homogeneity of the data were evaluated according to a critique of the regression triplet data, which examines the quality of the data for the proposed model. The evaluation was performed by means of a graphical (using rankit Q-Q graphs of residues and index graphs) and numerical statistical analysis of the residues.

The degree of accuracy and suitability of the rheological models were evaluated using the coefficient of determination $R^{2}$ and the sum of squared estimate of errors (SSE). The 
SSE is the sum of squares of the deviations of the data values from the predicted values (typically predicted from a Least Squares Analysis) using the general formula:

$$
S S E=\sum_{i=1}^{n}\left[y_{i}-f\left(x_{i}\right)\right]^{2}
$$

where $y_{i}$ is the $i$ th value of the variable to be predicted, $x_{i}$ is the $i$ th value of the explanatory variable, and $f\left(x_{i}\right)$ is the predicted value of $y_{i}$.

\section{Results and Discussion}

\subsection{Rheological Properties}

In the first phase, the mathematical description of the shear stress and shear strain rate dependence was carried out. For this purpose, the Bingham (B), Herschel-Bulkley $(\mathrm{H}-\mathrm{B})$, and Casson $(\mathrm{C})$ model were used. The results of the mathematical modelling are given in Tables 3 and 4 .

Table 3. Coefficients of the rheological models with an increasing shear strain rate $(n=3)$.

\begin{tabular}{|c|c|c|c|c|c|c|c|c|c|c|c|c|c|c|}
\hline \multirow{2}{*}{$\begin{array}{c}1 \rightarrow 500 \\
s^{-1}\end{array}$} & \multirow[b]{2}{*}{$\mathrm{T},{ }^{\circ} \mathrm{C}$} & \multicolumn{4}{|c|}{ Bingham Model } & \multicolumn{5}{|c|}{ Herschel-Bulkley Model } & \multicolumn{4}{|c|}{ Casson Model } \\
\hline & & $\begin{array}{c}\tau_{0} \\
(\mathbf{P a})\end{array}$ & $\begin{array}{c}\eta_{B} \\
(\mathbf{P a} \cdot \mathbf{s})\end{array}$ & SSE & $\mathbf{R}^{2}$ & $\begin{array}{c}\tau_{0} \\
(\mathbf{P a})\end{array}$ & $\underset{\left(\mathrm{Pa} \cdot \mathrm{s}^{\mathrm{n}}\right)}{\mathrm{K}}$ & n (-) & SSE & $\mathbf{R}^{2}$ & $\begin{array}{c}\tau_{0} \\
(\mathrm{~Pa})\end{array}$ & $\begin{array}{c}\eta_{C} \\
(\mathbf{P a} \cdot \mathbf{s})\end{array}$ & SSE & $\mathbf{R}^{2}$ \\
\hline \multirow{5}{*}{ EDC } & 36 & 22.27 & 1.572 & 19,340 & 0.9914 & 0.870 & 4.688 & 0.8185 & 1415 & 0.9994 & 5.865 & 1.276 & 6045 & 0.9973 \\
\hline & 38 & 23.21 & 1.456 & 17,460 & 0.9909 & 3.002 & 4.415 & 0.8158 & 1506 & 0.9992 & 6.704 & 1.168 & 5314 & 0.9972 \\
\hline & 40 & 19.79 & 1.360 & 10,640 & 0.9937 & 4.306 & 3.498 & 0.8429 & 825 & 0.9995 & 5.355 & 1.115 & 2844 & 0.9983 \\
\hline & 42 & 18.22 & 1.291 & 8090 & 0.9946 & 4.684 & 3.122 & 0.8531 & 487 & 0.9997 & 4.886 & 1.068 & 1888 & 0.9987 \\
\hline & 44 & 18.62 & 1.225 & 7402 & 0.9946 & 5.820 & 2.951 & 0.8537 & 587 & 0.9996 & 5.297 & 1.006 & 1768 & 0.9987 \\
\hline \multirow{5}{*}{ DC } & 36 & 32.92 & 1.462 & 5272 & 0.9973 & 22.28 & 2.788 & 0.8925 & 319 & 0.9998 & 9.959 & 1.133 & 1012 & 0.9995 \\
\hline & 38 & 31.68 & 1.389 & 5744 & 0.9967 & 20.48 & 2.814 & 0.8825 & 322 & 0.9998 & 10.050 & 1.075 & 886 & 0.9995 \\
\hline & 40 & 27.73 & 1.257 & 2731 & 0.9981 & 20.29 & 2.150 & 0.9105 & 225 & 0.9998 & 8.695 & 0.989 & 1007 & 0.9993 \\
\hline & 42 & 22.68 & 1.035 & 1700 & 0.9982 & 17.96 & 1.581 & 0.9293 & 626 & 0.9994 & 7.543 & 0.827 & 1705 & 0.9982 \\
\hline & 44 & 30.08 & 1.101 & 3728 & 0.9966 & 20.86 & 2.284 & 0.8785 & 144 & 0.9999 & 11.891 & 0.835 & 300 & 0.9997 \\
\hline \multirow{5}{*}{$\mathrm{MC}$} & 36 & 26.29 & 2.018 & 4058 & 99 & 18.29 & 2.927 & 0.9380 & 1001 & 97 & 3.724 & 1.718 & 2505 & 0.9993 \\
\hline & 38 & 21.51 & 1.702 & 835 & 0.9997 & 18.48 & 2.026 & 0.9709 & 373 & 0.9999 & 2.945 & 1.478 & 2644 & 0.9990 \\
\hline & 40 & 21.26 & 1.612 & 1116 & 0.9995 & 17.40 & 2.032 & 0.9614 & 371 & 0.9998 & 3.277 & 1.387 & 2225 & 0.9990 \\
\hline & 42 & 24.84 & 1.486 & 1022 & 0.9995 & 20.59 & 1.954 & 0.9544 & 148 & 0.9999 & 5.199 & 1.233 & 2054 & 0.9990 \\
\hline & 44 & 22.07 & 1.429 & 979 & 0.9995 & 19.80 & 1.670 & 0.9740 & 718 & 0.9996 & 4.137 & 1.210 & 3246 & 0.9982 \\
\hline \multirow{5}{*}{ WC } & 36 & 22.95 & 1.802 & 4749 & 0.9984 & 13.17 & 2.961 & 0.9173 & 33 & 0.9999 & 3.802 & 1.528 & 930 & 0.9997 \\
\hline & 38 & 21.04 & 1.606 & 3125 & 0.9987 & 13.29 & 2.509 & 0.9256 & 314 & 0.9999 & 3.743 & 1.364 & 915 & 0.9996 \\
\hline & 40 & 18.43 & 1.264 & 1541 & 0.9990 & 13.88 & 1.776 & 0.9433 & 450 & 0.9997 & 3.937 & 1.072 & 1266 & 0.9991 \\
\hline & 42 & 24.24 & 1.472 & 6122 & 0.9969 & 12.67 & 2.936 & 0.8851 & 310 & 0.9998 & 6.033 & 1.199 & 736 & 0.9996 \\
\hline & 44 & 24.27 & 1.393 & 3762 & 0.9979 & 15.84 & 2.410 & 0.9087 & 562 & 0.9997 & 6.141 & 1.135 & 951 & 0.9995 \\
\hline \multirow{5}{*}{$\mathrm{RB}$} & 36 & 16.07 & 1.385 & 1543 & 0.9991 & 11.05 & 1.951 & 0.9429 & 323 & 0.9998 & 2.709 & 1.205 & 853 & 0.9995 \\
\hline & 38 & 14.40 & 1.258 & 564 & 0.9996 & 11.32 & 1.593 & 0.9606 & 96 & 0.9999 & 2.410 & 1.104 & 703 & 0.9995 \\
\hline & 40 & 11.68 & 1.123 & 368 & 0.9997 & 9.80 & 1.323 & 0.9726 & 190 & 0.9998 & 1.848 & 1.002 & 784 & 0.9993 \\
\hline & 42 & 14.21 & 1.071 & 312 & 0.9997 & 12.07 & 1.302 & 0.9675 & 83 & 0.9999 & 2.944 & 0.929 & 808 & 0.9992 \\
\hline & 44 & 16.21 & 1.020 & 237 & 0.9997 & 14.98 & 1.149 & 0.9801 & 159 & 0.9998 & 3.857 & 0.868 & 1579 & 0.9983 \\
\hline
\end{tabular}


Table 4. Coefficients of the rheological models at a decreasing shear strain rate $(n=3)$.

\begin{tabular}{|c|c|c|c|c|c|c|c|c|c|c|c|c|c|c|}
\hline \multirow{2}{*}{$\begin{array}{c}500 \rightarrow 1 \\
\mathrm{~s}^{-1}\end{array}$} & \multirow[b]{2}{*}{$\mathrm{T},{ }^{\circ} \mathrm{C}$} & \multicolumn{4}{|c|}{ Bingham Model } & \multicolumn{5}{|c|}{ Herschel-Bulkley Model } & \multicolumn{4}{|c|}{ Casson Model } \\
\hline & & $\begin{array}{c}\tau_{0} \\
(\mathbf{P a})\end{array}$ & $\begin{array}{c}\eta_{B} \\
(\mathbf{P a} \cdot \mathbf{s})\end{array}$ & SSE & $\mathbf{R}^{2}$ & $\begin{array}{c}\tau_{0} \\
(\mathbf{P a})\end{array}$ & $\begin{array}{c}\mathrm{K} \\
\left(\mathrm{Pa} \cdot \mathbf{s}^{\mathrm{n}}\right)\end{array}$ & n (-) & SSE & $\mathbf{R}^{2}$ & $\begin{array}{c}\tau_{0} \\
(\mathbf{P a})\end{array}$ & $\begin{array}{c}\eta_{C} \\
(\mathbf{P a} \cdot \mathbf{s})\end{array}$ & SSE & $\mathbf{R}^{2}$ \\
\hline \multirow{5}{*}{ EDC } & 36 & 17.98 & 1.491 & 15,120 & 0.9925 & 0 & 4.071 & 0.8330 & 1310 & 0.9994 & 4.477 & 1.239 & 5004 & 0.9975 \\
\hline & 38 & 19.46 & 1.406 & 8048 & 0.9955 & 8.258 & 2.827 & 0.8837 & 2416 & 0.9986 & 4.428 & 1.175 & 3709 & 0.9979 \\
\hline & 40 & 18.12 & 1.319 & 6449 & 0.9959 & 8.750 & 2.480 & 0.8949 & 2410 & 0.9985 & 4.110 & 1.110 & 3481 & 0.9978 \\
\hline & 42 & 13.43 & 1.279 & 5338 & 0.9964 & 3.092 & 2.594 & 0.8823 & 623 & 0.9996 & 2.882 & 1.102 & 1660 & 0.9989 \\
\hline & 44 & 15.84 & 1.201 & 4332 & 0.9967 & 9.894 & 1.896 & 0.9238 & 2592 & 0.9980 & 3.344 & 1.029 & 3594 & 0.9972 \\
\hline \multirow{5}{*}{ DC } & 36 & 21.94 & 1.462 & 2087 & 0.9989 & 15.46 & 2.210 & 0.9312 & 128 & 0.9999 & 4.563 & 1.224 & 706 & 0.9996 \\
\hline & 38 & 21.26 & 1.380 & 2599 & 0.9985 & 14.18 & 2.213 & 0.9213 & 279 & 0.9998 & 4.801 & 1.149 & 761 & 0.9996 \\
\hline & 40 & 15.86 & 1.276 & 4457 & 0.9970 & 7.97 & 2.231 & 0.9069 & 1776 & 0.9988 & 3.541 & 1.086 & 1334 & 0.9991 \\
\hline & 42 & 20.85 & 1.016 & 1342 & 0.9986 & 18.84 & 1.232 & 0.9680 & 1134 & 0.9988 & 6.225 & 0.830 & 3254 & 0.9965 \\
\hline & 44 & 18.38 & 1.098 & 1160 & 0.9989 & 13.54 & 1.655 & 0.9316 & 63 & 0.9999 & 4.938 & 0.913 & 503 & 0.9995 \\
\hline \multirow{5}{*}{ MC } & 36 & 19.30 & 1.854 & 2625 & 0.9992 & 16.41 & 2.161 & 0.9744 & 2213 & 0 & 2.077 & 1.644 & 70 & 0.9988 \\
\hline & 38 & 15.28 & 1.665 & 219 & 0.9999 & 15.55 & 1.638 & 1.0030 & 216 & 0.9999 & 1.309 & 1.516 & 2461 & 0.9990 \\
\hline & 40 & 17.22 & 1.583 & 278 & 0.9999 & 17.28 & 1.577 & 1.0010 & 278 & 0.9999 & 1.814 & 1.419 & 3277 & 0.9985 \\
\hline & 42 & 18.93 & 1.461 & 1528 & 0.9992 & 22.00 & 1.170 & 1.0370 & 997 & 0.9995 & 2.134 & 1.303 & 7279 & 0.9962 \\
\hline & 44 & 11.85 & 1.436 & 2491 & 0.9987 & 8.95 & 1.748 & 0.9672 & 2086 & 0.9989 & 1.415 & 1.296 & 2011 & 0.9989 \\
\hline \multirow{5}{*}{ WC } & 36 & 17.60 & 1.658 & 1943 & 0.9992 & 16.17 & 1.806 & 0.9857 & 1840 & 0.9993 & 1.953 & 1.477 & 3757 & 0.9985 \\
\hline & 38 & 11.47 & 1.575 & 2314 & 0.9990 & 6.76 & 2.095 & 0.9524 & 1274 & 0.9994 & 1.276 & 1.427 & 956 & 0.9996 \\
\hline & 40 & 12.44 & 1.231 & 178 & 0.9999 & 11.13 & 1.367 & 0.9824 & 91 & 0.9999 & 1.737 & 1.102 & 854 & 0.9994 \\
\hline & 42 & 14.97 & 1.440 & 408 & 0.9998 & 12.63 & 1.688 & 0.9735 & 134 & 0.9999 & 1.950 & 1.281 & 1107 & 0.9994 \\
\hline & 44 & 10.92 & 1.385 & 2312 & 0.9987 & 6.88 & 1.832 & 0.9533 & 1542 & 0.9991 & 1.418 & 1.248 & 1280 & 0.9993 \\
\hline \multirow{5}{*}{ RB } & 36 & 12.630 & 1.373 & 1029 & 0.9994 & 12.301 & 1.407 & 0.9959 & 1023 & 0.9994 & 1.233 & 1.254 & 2768 & 0.9984 \\
\hline & 38 & 9.364 & 1.255 & 157 & 0.9999 & 9.067 & 1.285 & 0.9960 & 152 & 0.9999 & 0.856 & 1.162 & 895 & 0.9994 \\
\hline & 40 & 9.158 & 1.108 & 61 & 0.9999 & 8.859 & 1.138 & 0.9955 & 56 & 0.9999 & 1.035 & 1.018 & 755 & 0.9993 \\
\hline & 42 & 9.287 & 1.067 & 77 & 0.9999 & 9.355 & 1.060 & 1.0010 & 77 & 0.9999 & 1.109 & 0.979 & 876 & 0.9991 \\
\hline & 44 & 9.391 & 1.017 & 35 & 0.9999 & 9.561 & 1.001 & 1.0030 & 33 & 0.9999 & 1.231 & 0.929 & 862 & 0.9991 \\
\hline
\end{tabular}

From the coefficients of rheological models, it is evident that with an increasing shear deformation rate, the chocolate masses reach higher values of plastic viscosity $\left(\eta_{B}, \eta_{C}\right)$, resp. coefficient of consistency $(K)$ than with the decreasing shear strain rate. With the increasing temperature for the individual samples, these values decrease [20].

All three rheological models used confirmed the plasticity of the chocolate masses, respectively, the samples showed a certain (non-negligible) flow limit $[17,20]$, with the highest values of this limit being reached by DC and the lowest by RC. This may be due to the different proportions of non-fat and milk components [3,21].

The flow index $(n)$ in the Herschel-Bulkley model confirmed the shear thinning (with the yield stress value) behaviour $(n<1)$ of the chocolate masses, which were not significantly affected by the temperature. With a decreasing shear strain rate, the shear thinning behaviour, especially in the MC, WC, and RC samples, was insignificant.

As the high values of the coefficient of determination $R^{2}$ and low values of the sum of the squared estimate of errors SSE (Equation (5)) prove, the used rheological models are very suitable. The Herschel-Bulkley rheological model [22] seems to be the most suitable (based on the $\mathrm{R}^{2}$ and SSE values) for the chocolate masses, although the Casson model is also used for chocolate masses in the literature [19-21,23]. The values of the statistical indicators $\mathrm{R}^{2}$ and SSE are given in Table 5. 
Table 5. Values of the statistical indicators of the rheological models $(n=50)$.

\begin{tabular}{ccccccccccc}
\hline \multirow{2}{*}{ Model } & \multicolumn{3}{c}{ Coefficient of Determination $\mathbf{R}^{\mathbf{2}}$} & \multicolumn{4}{c}{ Sum of Squared Estimate of Errors SSE } \\
\cline { 2 - 9 } & Mean & Median & MIN & MAX & SD & Mean & Median & MIN & MAX & SD \\
\hline Bingham & 0.9980 & 0.9989 & 0.9909 & 0.9999 & 0.0023 & 3581 & 2200 & 35 & 19,340 & 4318 \\
Herschel-Bulkley & 0.9996 & 0.9998 & 0.9980 & 0.9999 & 0.0004 & 733 & 372 & 33 & 2592 & 729 \\
Casson & 0.9988 & 0.9991 & 0.9962 & 0.9997 & 0.0008 & 2034 & 1457 & 300 & 7279 & 1547 \\
\hline
\end{tabular}

MIN-minimal value, MAX—maximal value, SD—standard deviation, $\mathrm{H}-\mathrm{B}-$ Herschel-Bulkley model.

\subsection{Hysteresis Area}

Subsequently with rheological measurements, the hysteresis areas were calculated [16]. The highest values of the hysteresis area were reached by the MC and WC masses at a temperature of $36^{\circ} \mathrm{C}$; on the contrary, the lowest values were reached in the RC sample. All the area values are detailed in Table 6 .

Table 6. Hysteresis values of the chocolate masses $(n=3)$.

\begin{tabular}{|c|c|c|c|c|c|}
\hline Temperature, ${ }^{\circ} \mathrm{C}$ & $\mathrm{EDC},\left(\mathrm{Pa} \cdot \mathrm{s}^{-1}\right)$ & $\mathrm{DC},\left(\mathrm{Pa} \cdot \mathrm{s}^{-1}\right)$ & $\mathrm{MC},\left(\mathrm{Pa} \cdot \mathrm{s}^{-1}\right)$ & $\mathrm{WC},\left(\mathrm{Pa} \cdot \mathrm{s}^{-1}\right)$ & $\mathrm{RC},\left(\mathrm{Pa} \cdot \mathrm{s}^{-1}\right)$ \\
\hline 36 & 12814 & 7521 & 25787 & 21694 & 3625 \\
\hline 38 & 9531 & 6771 & 7953 & 8817 & 3147 \\
\hline 40 & 6554 & 3705 & 6156 & 7657 & 3266 \\
\hline 42 & 3901 & 3446 & 6892 & 9063 & 3238 \\
\hline 44 & 4924 & 6318 & 4501 & 8363 & 3952 \\
\hline
\end{tabular}

The magnitude of the hysteresis area was significantly affected by the temperature; with an increasing temperature, the value of area decreased and, thus, the degree of thixotropic behaviour of the chocolate masses. With an increasing temperature, the chocolate masses, with the exception of the RC masses, took less time to reaggregate their original structure [24]. An increase in the hysteresis area at $44^{\circ} \mathrm{C}$ was observed for the EDC and DC masses, due to the different structure of these high cocoa and low-fat masses [25].

\subsection{Pipe Flow Properties}

The compilation of the flow curves using the rheological models not only serves to determine the flow behaviour of liquids, but the values of the coefficients can be further used to model the physical-mechanical states of liquids, e.g., during their flow [26,27]. It is possible to calculate using the coefficients of the rheological models, for example, the mean and maximum flow velocity, volume and mass flow, coefficients of friction at the wallliquid interface, and Reynolds number, which can be used to distinguish laminar, transient, and turbulent flow, etc. [28]. Modelling the velocity profiles of a liquid after stabilisation of both two-dimensional and three-dimensional flow seems to be the most beneficial for technical practice. For Newtonian fluids, for which the viscosity does not change with an increasing shear strain rate, such modelling is quite common and simple [29-32], but for non-Newtonian models, it is more difficult [33,34].

During tempering and other methods of processing, chocolate masses are often transported by pipelines, where the velocity profiles can be modelled using modified relationships for non-Newtonian fluids.

For Newtonian fluids, the flow velocity at any point in the pipeline can be calculated according to:

$$
v=\frac{\Delta p}{4 \eta L\left(R^{2}-r^{2}\right)}
$$

where $v$ is the flow velocity, $\Delta p$ is the pressure drop in the pipe, $\eta$ is the dynamic viscosity, $L$ is the length of the pipe, $R$ is the radius of the pipe, and $r$ is the distance from the pipe axis.

By modifying Equation (6), it is possible to obtain the following Equations (7)-(9), which are not widely used in the FoodTech sciences, but rather in construction materials [35], medicine and pharmaceuticals [36], the chemical industry [37], and specific 
polymeric materials [38]. However, as demonstrated above, these relationships are also applicable for the purpose of modelling the flow behaviour of foods and food raw materials.

To calculate the flow velocity of Bingham fluids, it is necessary to adjust the relationship and introduce the appropriate coefficients of the model [39]:

$$
v=\frac{\Delta p R^{2}}{4 L \eta_{B}}\left[1-\left(\frac{r}{R}\right)^{2}\right]-\frac{r \tau_{0}}{\eta_{B}}\left(1-\frac{r}{R}\right)
$$

where $\eta_{B}$ is the Bingham plastic viscosity and $\tau_{0}$ is the yield stress (using Bingham rheological model).

To calculate the flow velocity of liquids described by the Herschel-Bulkley rheological model, it is necessary to adjust the relationship and introduce the appropriate coefficients of the model [40]:

$$
v=\frac{n}{1+n}\left(\frac{\Delta p}{L K}\right)^{\frac{1}{n}}\left[\left(R-R_{*}\right)^{\frac{n+1}{n}}-\left(r-R_{*}\right)^{\frac{n+1}{n}}\right]
$$

where the plug radius $R_{*}=\frac{2 L \tau_{0}}{\Delta p}, n$ is the flow index, $K$ is the consistency coefficient, and $\tau_{0}$ is the yield stress (using Herschel-Bulkley rheological model).

To calculate the flow velocity of liquids described by Casson's rheological model, it is necessary to adjust the relationship and introduce the appropriate coefficients of the model [41]:

$$
v=\frac{R \tau_{w}}{2 \eta_{C}^{2}}\left\{\left[1-\left(\frac{r}{R}\right)^{2}\right]-\frac{8}{3}\left(\frac{\tau_{0}}{\tau_{w}}\right)^{\frac{1}{2}}\left[1-\left(\frac{r}{R}\right)^{\frac{3}{2}}\right]+2 \frac{\tau_{0}}{\tau_{w}}\left(1-\frac{r}{R}\right)\right\}
$$

where the wall stress $\tau_{w}=\frac{\Delta p R}{2 L}, \eta_{C}$ is the Casson plastic viscosity, and $\tau_{0}$ is the yield stress (using Bingham rheological model).

Using coefficients of the rheological models (Equations (1)-(4)) and formulas above (Equations (7)-(9)), it is possible to model the $2 \mathrm{D}$ velocity profiles. If we consider the standard diameter of the pipe, $D=50 \mathrm{~mm}$; the length of the pipe, $L=1 \mathrm{~m}$; and the pressure drop, $\Delta p=10 \mathrm{kPa}$, the different flow behaviours of chocolate masses can be seen from Figures 1-3. The $x$-axis on Figures $1-5$ shows $r / R$, which is the dimensionless ratio of the distance from the pipeline axis to the fixed radius of the pipeline $(D / 2)$. It is certain that in the axis of the pipeline, the highest flow velocity is always the highest for real liquids.

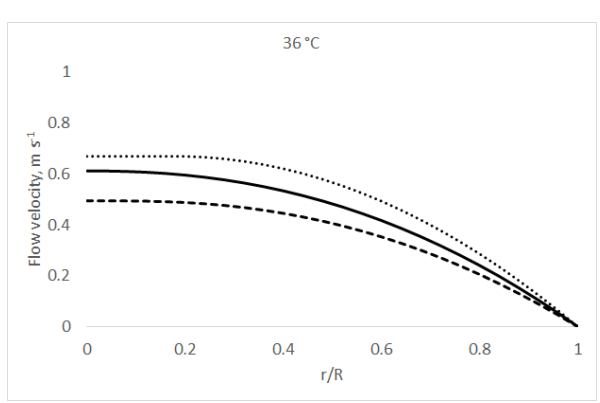

(a)

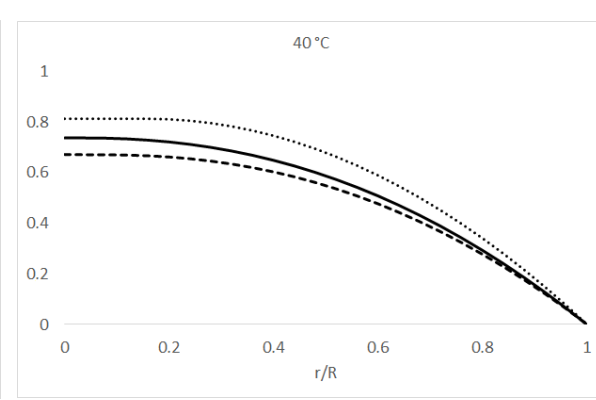

(b)

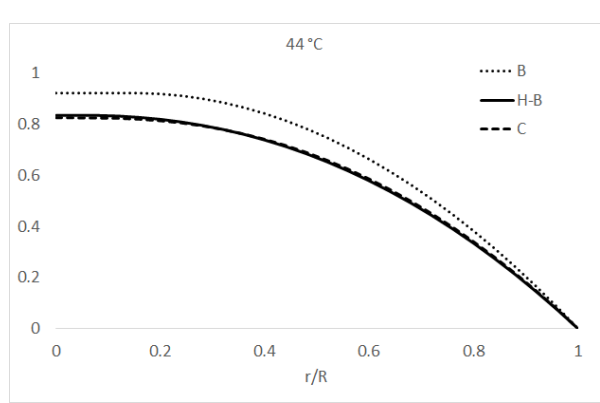

(c)

Figure 1. EDC velocity profiles: at (a) $36^{\circ} \mathrm{C}$; at (b) $40{ }^{\circ} \mathrm{C}$; and at (c) $44{ }^{\circ} \mathrm{C}$.

Figure 1 models the EDC sample flow velocity using all three rheology models (1)-(3) and Equations (6)-(8) used above at temperatures of 36,40 , and $44^{\circ} \mathrm{C}$.

Figure 2 models the flow velocity of the MC sample using the Herschel-Bulkley model (Equation (2)) coefficients and Equation (8). The figure shows the temperature dependence of this chocolate mass, when the mass flows the fastest and vice versa at the highest temperature $\left(44^{\circ} \mathrm{C}\right)[20,21,42]$. 


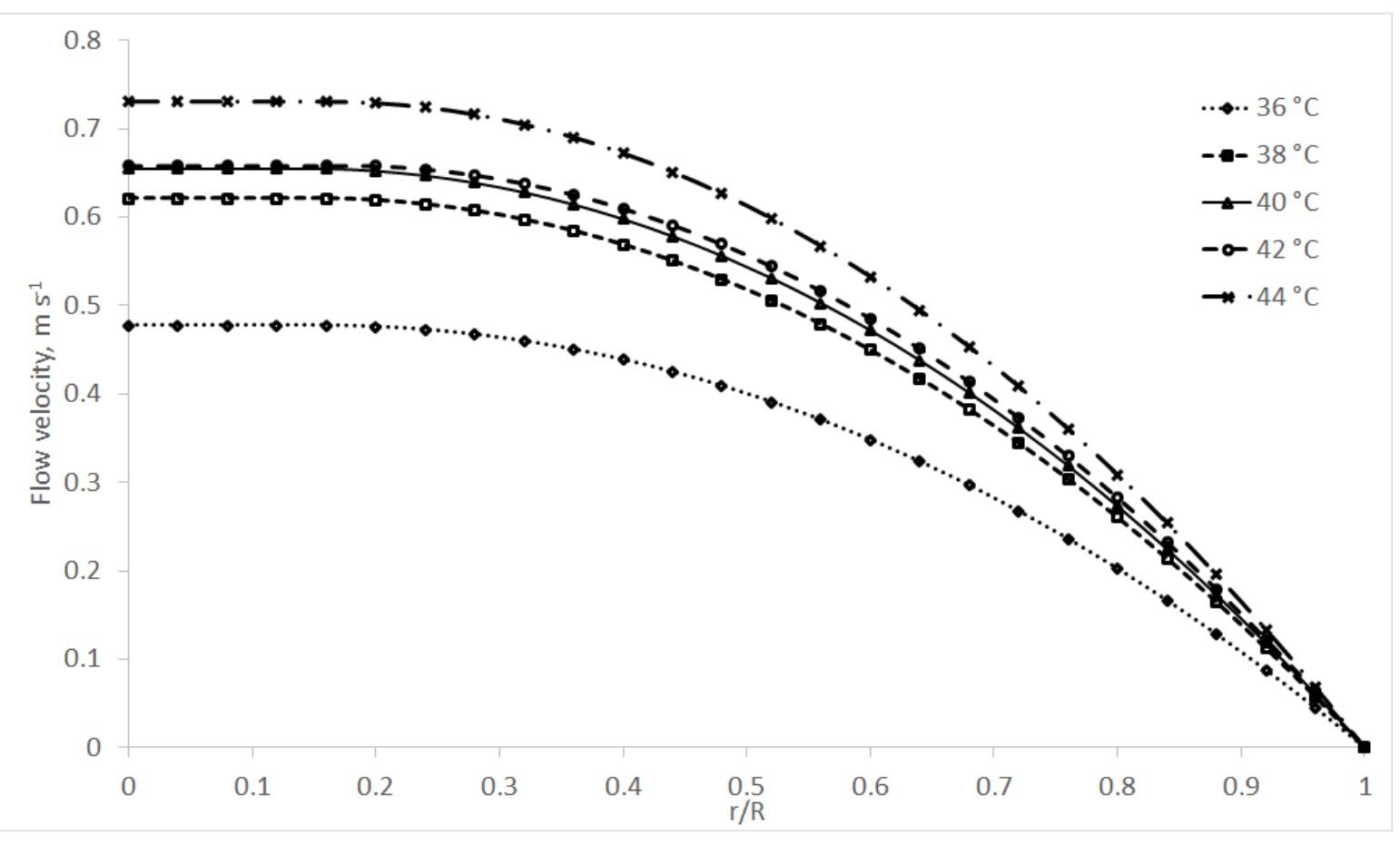

Figure 2. MC velocity profiles at temperatures of $36-44^{\circ} \mathrm{C}$ using the $\mathrm{H}-\mathrm{B}$ model.

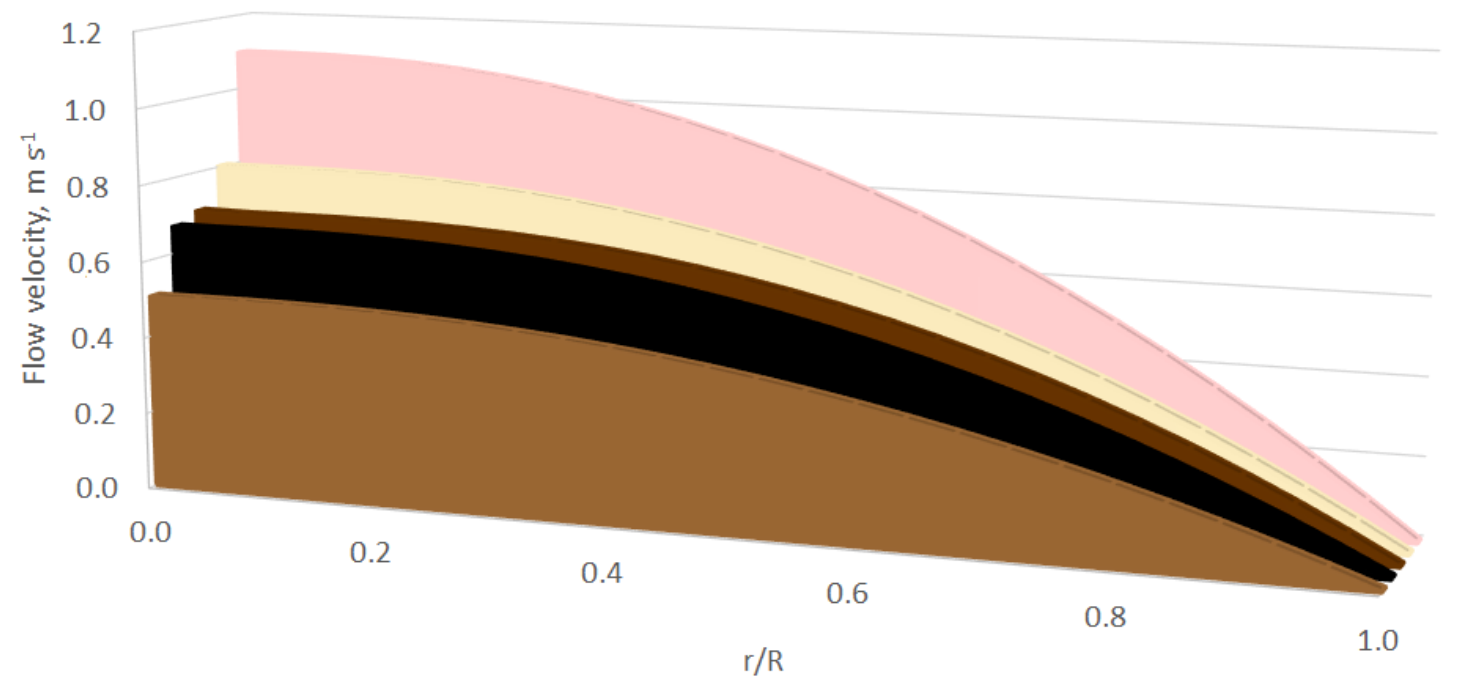

$\mathrm{MC} \square \mathrm{EDC} \square \mathrm{DC} \quad \mathrm{WC} \mathrm{RC}$

Figure 3. 2D velocity profiles of the chocolate masses at $40^{\circ} \mathrm{C}$ using the Casson model. 

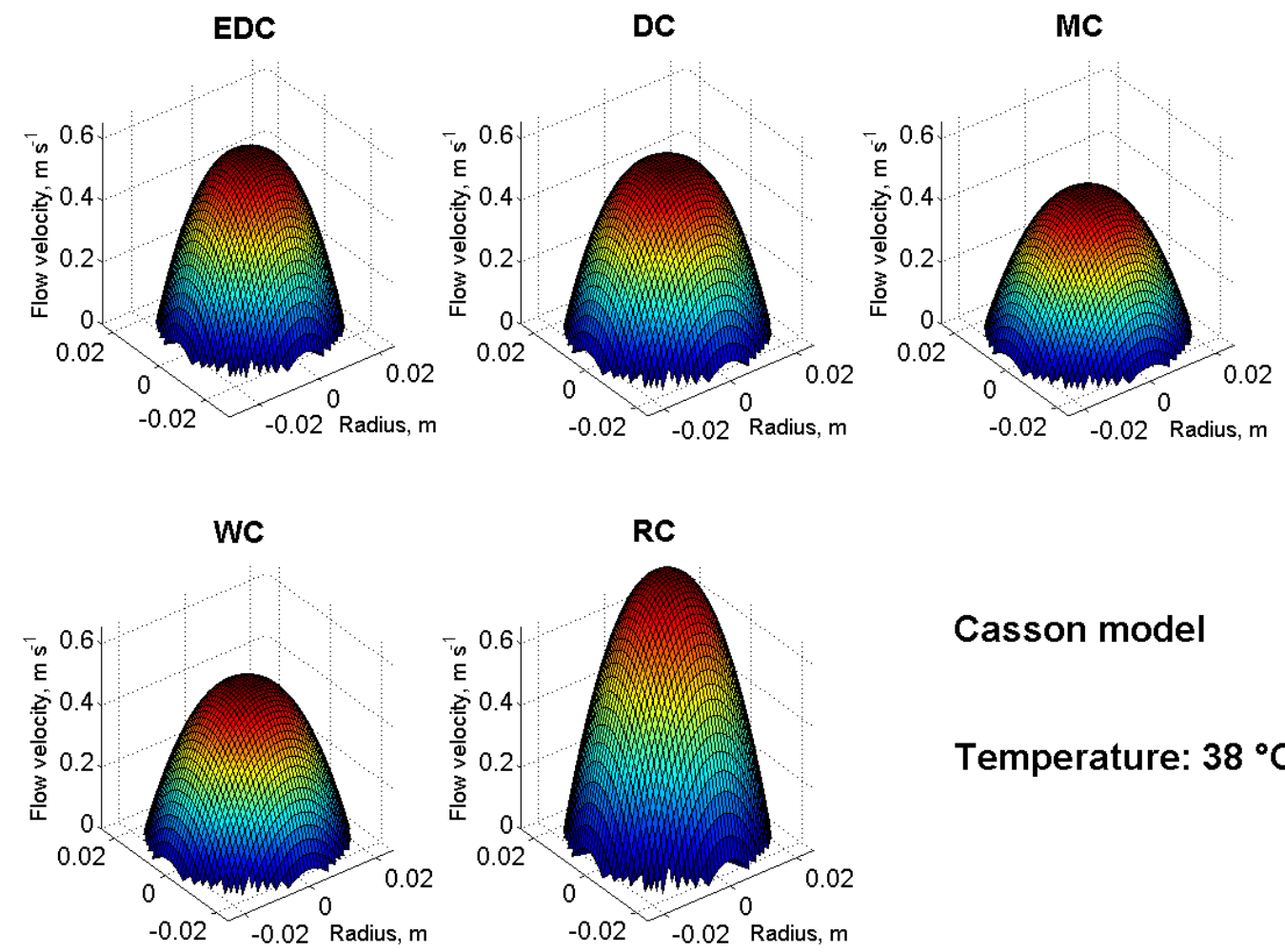

\section{Casson model}

\section{Temperature: $38^{\circ} \mathrm{C}$}

Figure 4. 3D velocity profiles of the chocolate masses at $38^{\circ} \mathrm{C}$ using the Casson model.
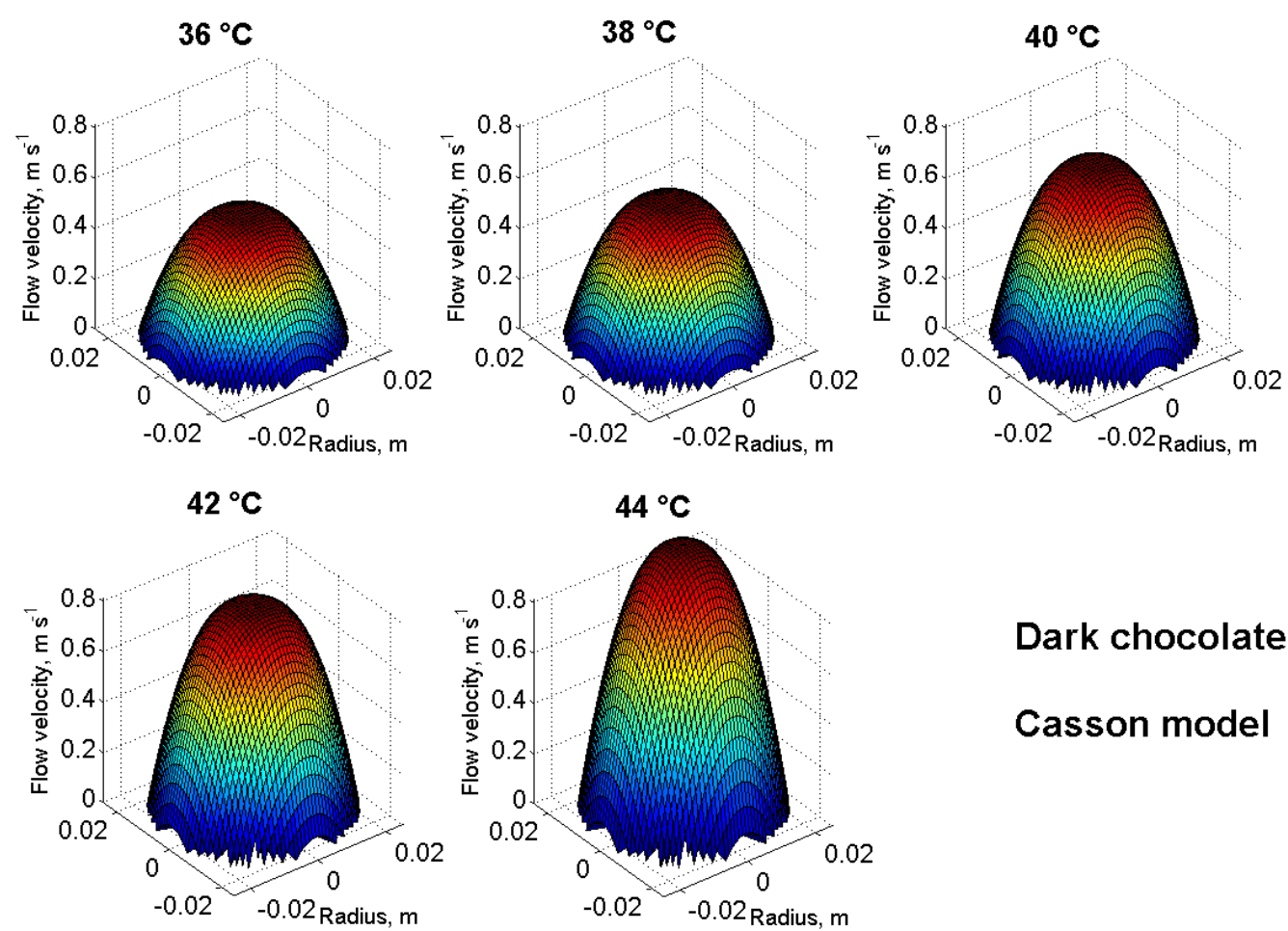

\section{Dark chocolate}

Casson model

Figure 5. 3D velocity profiles at $36-44{ }^{\circ} \mathrm{C}$ of DC using the Casson model.

Figure 3 illustrates the different flow velocities of all five chocolate masses at a comparative temperature of $40^{\circ} \mathrm{C}$. In this case, Casson model (Equations (3) and (9)) were used.

In the above figures, the non-Newtonian behaviour of the chocolate masses can be seen, where the flow front is typically flattened, as reported by, for example $[40,43]$. This 
can, of course, cause complications in real technical practice-e.g., turbulence [44], even when using the current trends in the food industry, such as 3D food printing, where problems may occur with the supply of the liquid or semi-liquid raw material to the nozzle, clogging of the nozzle itself, etc. [45,46].

For a realistic idea and comparison of the flow properties of the samples, it is appropriate to supplement the modelling with three-dimensional velocity profiles of flowing chocolate masses. Figures 4 and 5 were created by rotating Equations (7)-(9) around the pipeline axis using Matlab. Figure 4 shows the velocity profiles of all five chocolate masses used at a reference temperature of $38^{\circ} \mathrm{C}$ and using the Casson model (Equations (3), (4) and (9)). Under the same conditions (temperature, length and diameter of the pipeline, and pressure drop), the chocolate masses show different flow velocities and partly also the shapes of the $3 \mathrm{D}$ velocity profile. In Figure 5, the DC velocity profiles at temperatures from $36^{\circ} \mathrm{C}$ to $44^{\circ} \mathrm{C}$ are modelled as an example using the Casson model (Equations (3), (4) and (9)). It can be seen from the figure that with an increasing temperature, the DC flow velocity also increased and the velocity profile approached a Newtonian liquid in shape.

If the flow front in Figures 4 and 5 is flattened, it is a non-Newtonian behaviour, or transient or turbulent [47] flow may also occur. This would then be interesting for further research, such as the calculation of the Reynolds number. However, this is also possible using the coefficients of rheological models, see [28].

\section{Conclusions}

Based on the obtained experimental and calculated results and their discussion, it can be stated that both hypotheses were confirmed.

With an increasing temperature, the plastic viscosity or the consistency (depend on rheological model) of the chocolate masses also resulted in an increase in the flow velocity of the chocolate masses in the pipe. The size of the hysteresis area decreased with an increasing temperature and, thus, the degree of the thixotropic behaviour of the chocolate masses. Thus, with an increasing temperature, the chocolate masses, with the exception of the RC masses, needed less time to reaggregate their structure.

The Bingham, Herschel-Bulkley and Casson rheological models can be successfully used to construct the flow curves of the chocolate masses. According to statistical preachers $\left(\mathrm{R}^{2}\right.$, SSE), the Herschel-Bulkley and Casson rheological models appear to be the most suitable. The coefficients of the rheological models can be used for further modelling. For example, the $2 \mathrm{D}$ and $3 \mathrm{D}$ velocity profiles that are very well applicable in practice. The technical equations used to model the flow velocity of liquids at any point between the axis and the pipeline wall can be successfully used to model other foods and food raw materials with plastic or pseudoplastic rheological behaviour.

The results of modelling the flow behaviour of the food and food raw materials can be used in conventional technical practice in the design of technological equipment structures and in current trends in the food industry, such as 3D food printing.

Author Contributions: Conceptualization: V.K. (Vojtěch Kumbár) and L.H.; methodology: V.K. (Vojtěch Kumbár), J.V. and L.H.; validation: V.K. (Vojtěch Kumbár), V.K. (Veronika Kouřilová) and L.H.; formal analysis: V.K. (Vojtěch Kumbár), V.K. (Veronika Kouřilová), R.D. and L.H.; investigation: V.K. (Vojtěch Kumbár), V.K. (Veronika Kouřilová), R.D., J.V. and L.H.; data curation: V.K. (Vojtěch Kumbár); re-sources: V.K. (Vojtěch Kumbár) and L.H.; writing-original draft preparation: V.K. (Vojtěch Kumbár), V.K. (Veronika Kouřilová) and R.D.; project ad-ministration: V.K. (Vojtěch Kumbár); funding acquisition: V.K. (Vojtěch Kumbár). All authors have read and agreed to the published version of the manuscript.

Funding: This research was funded by the Internal Grant Agency of the Faculty of AgriSciences no. AF-IGA-2020-TP006 "Modelling of rheological properties of liquid and semi-liquid food raw materials and foods showing non-Newtonian behaviour".

Institutional Review Board Statement: Not applicable.

Informed Consent Statement: Not applicable. 
Data Availability Statement: The data presented in this study are available on request from the corresponding author.

Conflicts of Interest: The authors declare no conflict of interest. The funders had no role in the design of the study; in the collection, analyses, or interpretation of data; in the writing of the manuscript; or in the decision to publish the results.

\section{References}

1. Selvasekaran, P.; Chidambaram, R. Advances in formulation for the production of low-fat, fat-free, low-sugar, and sugar-free chocolates: An overview of the past decade. Trends Food Sci. Technol. 2021, 113, 315-334. [CrossRef]

2. Directive (EC) No 36/2000 of the European parliament and of the council of 23 June 2000 relating to cocoa and chocolate products intended for human consumption. OJ L 197 2000, 3, 19.

3. Afoakwa, E.O. Chocolate Science and Technology, 1st ed.; Willey Blackwell: York, UK, 2010; 275p.

4. Glicerina, V.; Balestra, F.; Dalla Rosa, M.; Romani, S. Microstructural and rheological characteristics of dark, milk and white chocolate. J. Food Eng. 2016, 169, 165-171. [CrossRef]

5. Martinez-Inchausti, A. Legal aspects of chocolate manufacture. In Industrial Chocolate Manufacture and Use, 4th ed.; Beckett, S.T., Ed.; Wiley Online Library: Hoboken, NJ, USA, 2009; pp. 576-594. [CrossRef]

6. Dumarche, A.; Troplin, P.; Bernaert, H.; Lechevalier, P.; Beerens, H.; Landuyt, A. Process for Producing Cocoa-Derived Material. European Patent EP2237677B1, 13 June 2012.

7. Tuenter, E.; Sakavitsi, M.E.; Rivera-Mondragon, A.; Hermans, N.; Foubert, K.; Halabalaki, M.; Pieters, L. Ruby chocolate: A study of its phytochemical composition and quantitative comparison with dark, milk and white chocolate. Food Chem. 2021, $343,1-12$. [CrossRef] [PubMed]

8. Montoya, C.C.; Valencia, W.G.; Sierra, J.A.; Penagos, L. Enhanced pink-red hues in processed powders from unfermented cacao beans. LWT 2021, 138, 110671. [CrossRef]

9. Lillah, A.; Asghar, I.; Pasha, G.; Murtaza, M.A. Improving heat stability along with quality of compound dark chocolate by adding optimized cocoa butter substitute (hydrogenated palm kernel stearin) emulsion. LWT-Food Sci. Technol. 2017, 80, 531-536. [CrossRef]

10. Żyżelewicz, D.; Budryn, G.; Oracz, J.; Antolak, H.; Kregiel, D.; Kaczmarska, M. The effect on bioactive components and characteristics of chocolate by functionalization with raw cocoa beans. Food Res. Int. 2018, 113, 234-244. [CrossRef]

11. Juszczak, L.; Witczak, M.; Fortuna, T.; Banys, A. Rheological properties of commercial mustards. J. Food Eng. 2004, 63, $209-271$. [CrossRef]

12. Beckett, S.T. The Science of Chocolate, 1st ed.; Royal Society of Chemistry Paperbacks: London, UK, 2000; 175p.

13. Balmforth, N.J.; Frigaard, I.A.; Ovarlez, G. Yielding to Stress: Recent Developments in Viscoplastic Fluid Mechanics. Annu. Rev. Fluid Mech. 2014, 46, 121-146. [CrossRef]

14. Tran, P.D.; Van Durme, J.; Van de Walle, D.; de Winne, A.; Delbaere, C.; de Clercq, N.; Dewettinck, K. Quality attributes of dark chocolate produced from vietnamese cocoa liquors. J. Food Qual. 2016, 39, 311-322. [CrossRef]

15. Hinneh, M.; Van de Walle, D.; Haeck, J.; Abotsi, E.E.; De Winne, A.; Saputro, A.D.; Dewettinck, K. Applicability of the melanger for chocolate refining and stephan mixer for conching as small-scale alternative chocolate production techniques. J. Food Eng. 2019, 253, 59-71. [CrossRef]

16. Přidal, A.; Trávníček, P.; Kudělka, J.; Nedomová, Š.; Ondrušíková, S.; Trost, D.; Kumbár, V. A rheological analysis of biomaterial behaviour as a tool to detect the dilution of heather honey. Materials 2021, 14, 2472. [CrossRef]

17. Bergemann, N.; Heil, M.; Smith, B.; Juel, A. From elastic deformation to flow in tempered chocolate. J. Rheol. 2018, 62, 1187-1195. [CrossRef]

18. Kumbár, V.; Nedomová, Š.; Trnka, J.; Buchar, J.; Pytel, R. Effect of storage duration on the rheological properties of goose liquid egg products and eggshell membranes. Poult. Sci. 2016, 95, 1693-1701. [CrossRef] [PubMed]

19. Lannes, S.C.S.; Medeiros, M.L.; Gioielli, L.A. Rheological properties of cupuassu and cocoa fats. Grasas Y Aceites 2004, 55, 115-121. [CrossRef]

20. Fernandes, V.A.; Müller, A.J.; Sandoval, A.J. Thermal, structural and rheological characteristics of dark chocolate with different compositions. J. Food Eng. 2013, 116, 97-108. [CrossRef]

21. Hřivna, L.; Machálková, L.; Burešová, I.; Nedomová, Š.; Gregor, T. Texture, color, and sensory changes occurring in chocolate bars with filling during storage. Food Sci. Nutr. 2021, 9, 4863-4873. [CrossRef]

22. de Jesus Silva, G.; Gonçalves, B.R.F.; de Jesus, J.C.; Vidigal, M.C.T.R.; Minim, L.A.; Ferreira, S.O.; Ferrão, S.P.B. Study of the structural properties of goat's milk chocolates with different concentrations of cocoa mass. J. Texture Stud. 2019, 50, 547-555. [CrossRef]

23. Eduardo, M.F.; Correa De Mello, K.G.P.; Polakiewicz, B.; Da Silva Lannes, S.C. Evaluation of chocolate milk beverage formulated with modified chitosan. J. Agric. Sci. Technol. 2014, 16, 1301-1312.

24. Sikora, M.; Adamczyk, G.; Krystyjan, M. Thixotropy as a measure of liquid food producs. Food Sci. Technol. Qual. 2011, 18, 5-14. [CrossRef]

25. Servais, C.; Ranc, H.; Roberts, I.D. Determination of chocolate viscosity. J. Texture Stud. 2003, 34, 467-497. [CrossRef] 
26. Vlaev, S.D.; Staykov, P.; Popov, R. Pressure distribution at impeller blades of some radial flow impellers in saccharose and xanthan gum solutions: A CFD visualization approach. Food Bioprod. Process. 2004, 82, 13-20. [CrossRef]

27. Žitný, R.; Landfeld, A.; Skočilas, J.; Štancl, J.; Flegl, V.; Zachariášová, M.; Houška, M. Hydraulic characteristic of collagen. Czech J. Food Sci. 2015, 33, 479-485. [CrossRef]

28. Kumbár, V.; Strnková, J.; Nedomová, Š.; Buchar, J. Fluid dynamics of liquid egg products. J. Biol. Phys. 2015, 41, 303-311. [CrossRef] [PubMed]

29. Kumbár, V.; Polcar, A.; Votava, J. Physical and mechanical properties of bioethanol and gasoline blends. Listy Cukrov. A Reparske 2015, 131, 112-115.

30. Devakar, M.; Raje, A. Modelling and analysis of the unsteady flow and heat transfer of immiscible micropolar and newtonian fluids through a pipe of circular cross section. J. Braz. Soc. Mech. Sci. Eng. 2018, 40, 1-18. [CrossRef]

31. Arosemena, A.A.; Andersson, H.I.; Solsvik, J. Turbulent channel flow of generalized newtonian fluids at a low reynolds number. J. Fluid Mech. 2021, 908, A43. [CrossRef]

32. Nedomová, Š.; Kumbár, V.; Pytel, R.; Buchar, J. Mechanical properties of sugar beet root during storage. Int. Agrophys. 2017, 31, 507-513. [CrossRef]

33. Mehta, D.; Radhakrishnan, A.K.T.; van Lier, J.; Clemens, F. A wall boundary condition for the simulation of a turbulent non-newtonian domestic slurry in pipes. Water 2018, 10, 124. [CrossRef]

34. Baranovskii, E.S. A novel 3D model for non-newtonian fluid flows in a pipe network. Math. Methods Appl. Sci. 2021, 44, 3827-3839. [CrossRef]

35. Clauss, J. Taming turbulent piping-system flow. HPAC Heat. Pip. AirCond. Eng. 2009, 81, 36-43.

36. Xue, H.; Fung, Y.C. Persistence of asymmetry in nonaxisymmetric entry flow in a circular cylindrical tube and its relevance to arterial pulse wave diagnosis. J. Biomech. Eng. 1989, 111, 37-41. [CrossRef]

37. Jirkovsky, L.; Boot, L.M. Numerical tests of a new molecule-dependent momentum transport equation. Phys. A Stat. Mech. Appl. 2008, 387, 5012-5016. [CrossRef]

38. Edomwonyi-Otu, L.C. Distortion of velocity profiles of water flow with heavy molecular weight polymers. Defect Diffus. Forum 2019, 392, 228-238. [CrossRef]

39. Simpson, M.M.; Janna, W.S. Newtonian and non-newtonian fluids: Velocity profiles, viscosity data, and laminar flow friction factor equations for flow in a circular duct. In Proceedings of the ASME International Mechanical Engineering Congress and Exposition, Lake Buena Vista, FL, USA, 13-19 November 2009; Volume 9, pp. 173-180. [CrossRef]

40. Wiklund, J.; Stading, M.; Trägårdh, C. Monitoring liquid displacement of model and industrial fluids in pipes by in-line ultrasonic rheometry. J. Food Eng. 2010, 99, 330-337. [CrossRef]

41. Das, B.; Bishop, J.J.; Kim, S.; Meiselman, H.J.; Johnson, P.C.; Popel, A.S. Red blood cell velocity profiles in skeletal muscle venules at low flow rates are described by the casson model. Clin. Hemorheol. Microcirc. 2007, 36, 217-233.

42. Ardakani, H.A.; Mitsoulis, E.; Hatzikiriakos, S.G. Capillary flow of milk chocolate. J. Non-Newton. Fluid Mech. 2014, 210 , 56-65. [CrossRef]

43. Pegoraro, P.R.; Marangoni, M.; Gut, J.A.W. Residence time distribution models derived from non-ideal laminar velocity profiles in tubes. Chem. Eng. Technol. 2012, 35, 1593-1603. [CrossRef]

44. Song, K.; Al-Salaymeh, A.; Jovanovic, J.; Rauh, C.; Delgado, A. Experimental in situ investigations of turbulence under high pressure. Ann. N. Y. Acad. Sci. 2010, 1189, 24-33. [CrossRef] [PubMed]

45. Zelený, P.; Růžička, V. The design of the 3D printer for use in gastronomy. Mod. Mach.(MM) Sci. J. 2017, 1744-1747. [CrossRef]

46. Rando, P.; Ramaioli, M. Food 3D printing: Effect of heat transfer on print stability of chocolate. J. Food Eng. 2021, $294,110415$. [CrossRef]

47. Walker, J.H. Bulk chocolate handling. In Industrial Chocolate Manufacture and Use, 4th ed.; Beckett, S.T., Ed.; Wiley Online Library: Hoboken, NJ, USA, 2009; pp. 247-260. [CrossRef] 